\title{
Body Image Negatif Berhubungan Dengan Rendahnya Aktifitas Fisik Pada Remaja Putri Wilayah Puskesmas Pasundan Kota Samarinda
}

\author{
${ }^{I}$ Zakina Octaviano \\ ${ }^{2}$ Annisa Nurrachmawati \\ ${ }^{3}$ Reny Noviasty
}

\begin{abstract}
${ }^{1}$ Departemen Promosi Kesehatan Universitas Mulawarman Indonesia
${ }^{2}$ Departemen Biostatistika, Kependudukan, dan Kesehatan Reproduksi, Fakultas Kesehatan Masyarakat, Universitas Mulawarman Indonesia

${ }^{3}$ Departemen Gizi Kesehatan Fakultas Kesehatan Masyarakat, Universitas Mulawarman,Indonesia
\end{abstract}

Alamat Korespondensi:
Reny Noviasty
Gizi masyarakat
Universitas Mulwarman
Institusi penulis
+628114440914
Email: renynoviastyfkm@gmail.com

https://doi.org/10.37362/jkph.v6i1.371 


\begin{abstract}
ABSTRAK
Remaja putri cenderung lebih berisiko mengalami permasalahan kesehatan, terutama mengenai citra tubuh (body image) dan status gizi. Aktivitas fisik bermanfaat untuk kesehatan fisik dan psikologis. Frekuensi aktivitas fisik menurun secara signifikan pada remaja putri pada saat mencapai usia 17 tahun. Tujuan penelitian ini yaitu untuk mengetahui hubungan body image dan status gizi dengan aktivitas fisik siswi kelas X dan XI di SMA dan SMK swasta wilayah kerja puskesmas pasundan Kota Samarinda tahun 2019. Desain yang digunakan yaitu cross sectional study dengan 141 orang siswi, teknik pengambilan sampel secara stratified random sampling. Data variabel body image diambil dengan menggunakan kuesioner MBSRQ-AS, status gizi ditentukan menggunakan perhitungan IMT yang didapatkan dari pengukuran antropometri dan data aktivitas fisik diambil dengan menggunakan kuesioner PAQ-A. Analisa data menggunakan uji korelasi Spearman Rank. Hasil analisis penelitian menunjukkan sebesar $(49,6 \%)$ responden berusia 16 tahun. Mayoritas mempunyai aktivitas fisik rendah $(62,4 \%)$, body image negatif $(66,0 \%)$, dan mempunyai status gizi normal $(66,0 \%)$. Analisis bivariat menunjukkan bahwa terdapat hubungan yang signifikan antara body image dan aktivitas fisik $(\mathrm{p}=0,005)$. Tidak terdapat hubungan yang signifikan antara status gizi dengan aktivitas fisik $(\mathrm{p}=0,401)$. Kesimpulan yang diperoleh yaitu hasil analisis menunjukkan kecenderungan semakin negatif body image maka semakin rendah aktivitas fisik. Perlu adanya modifikasi metode pembelajaran yang melibatkan aktifitas fisik di sekolah serta edukasi yang intensif dari pihak puskesmas untuk meningkatkan aktifitas fisik melalui perbaikan persepsi terhadap body image pada remaja putri
\end{abstract}

Kata Kunci : Remaja putri, body image, status gizi, aktivitas fisik

\begin{abstract}
Girls adolescent tend to be more at risk of experiencing health problems, especially regarding body image and nutritional status. Physical activity is beneficial for physical and psychological health. The frequency of physical activity decreases significantly in girls adolescent when they reach 17 years of age. The aim of this study was to determined the corelation between body image and nutritional status with the physical activity of grade X and XI students in private high schools and vocational schools in the working area of Puskesmas Pasundan Samarinda. The research design was a cross-sectional study with 141 female students, the sampling technique was stratified random sampling. Body image data were taken using the MBSRQ-AS questionnaire, nutritional status was determined using BMI calculations obtained from anthropometric measurements and physical activity data were collected using the PAQ-A questionnaire. Data analysis used the Spearman Rank trial. The results of the research analysis showed that (49.6\%) of the respondents were 16 years old. The majority have low physical activity (62.4\%), negative body image (66.0\%), and have normal nutritional status (66.0\%). Bivariate analysis showed that there was a significant corelation between body image and physical activity $(p=0.005)$. There was no significant corelation between nutritional status and physical activity $(p=0.401)$. The conclusion is that the more negative body image tends to be, the lower the physical activity. There needs to be a modification of learning methods that involve physical activity in High School as well as intensive education from the Health Center to increase physical activity through perceptions of body image in girls adolescent.
\end{abstract}

Keywords: Girls Adolescent, body image, nutritional status, physical activity 


\section{PENDAHULUAN}

Data dari tahun ke tahun secara nasional, Indonesia belum menunjukkan adanya perbaikan perilaku sehat terkait dengan aktivitas fisik. Data riskesdas tahun 2007 menunjukkan prevalensi nasional penduduk yang kurang melakukan aktivitas fisik pada usia > 10 tahun yaitu sebesar 48,2\% (Kementerian Kesehatan RI, 2008) dari total penduduk Indonesia, mengalami penurunan di Tahun 2013 $(26,1 \%)$ (Kementerian Kesehatan RI, 2013) dan kembali meningkat menjadi $33,5 \%$ di tahun 2018 (Kementerian Kesehatan RI, 2018). Sementara untuk wilayah Provinsi Kalimantan Timur mempunyai prevalensi sebesar $61,7 \%$ pada tahun 2007 (Kementerian Kesehatan RI, 2008), sementara pada tahun 2013 menjadi 35,7\% (Kementerian Kesehatan RI, 2013) dan semakin meningkat menjadi sebesar $40,0 \%$ diatas rata - rata nasional pada tahun 2018 (Kementerian Kesehatan RI, 2018).

Rekomendasi WHO mengenai aktivitas fisik pada anak - anak dan remaja usia 5 - 17 tahun setidaknya melakukan aktivitas fisik selama 60 menit dengan intensitas sedang hingga kuat untuk setiap harinya (WHO, 2010). Data secara global menunjukkan $81 \%$ remaja yang bersekolah di usia 11-17 tahun tidak aktif secara fisik pada tahun 2010, yaitu mereka melakukan aktivitas fisik intensitas sedang hingga berat kurang dari 60 menit setiap hari, seperti yang direkomendasikan oleh WHO (WHO, 2018). Sementara data WHO menunjukkan bahwa remaja putri yang masih duduk dibangku sekolah, diindikasi kurang aktif secara fisik dibandingkan pada remaja laki-laki, yaitu $84 \%$ berbanding $78 \%$ yang tidak memenuhi rekomendasi WHO (WHO, 2018).

Beberapa faktor risiko yang membuat rendahnya aktivitas fisik pada remaja putri diantaranya yaitu status gizi dan body image. Secara umum remaja putri di identifikasi sebagai kelompok khusus yang rentan terhadap permasalahan gizi ganda yaitu kekurangan gizi dan kelebihan berat badan (overweight) serta kegemukan (obesitas) (Dieny, 2014). Berdasarkan penelitian Putra (2018) didapatkan hasil bahwasannya remaja putri yang mempunyai IMT lebih akan lebih aktif terlibat dalam aktivitas fisik kategori berat, sedangkan remaja putri yang mempunyai status gizi kurang cenderung melakukan aktivitas fisik ringan (Putra et al., 2018).

Perubahan fisik dan tingkat mobilitas yang rendah pada masa remaja secara tidak langsung akan mempengaruhi perkembangan psikologis remaja dan saling beriiringan dengan gangguan body 
image (citra tubuh) (Kawuwung et al., 2015).

Salah satu efek dari persepsi terhadap body image (citra tubuh) remaja putri yaitu terjadinya gangguan pola makan yang tidak sehat atau yang lebih dikenal dengan eating disorder dan perubahan pola aktivitas fisik (Putra, 2017). Menurut Kololo (2012) secara psikologis remaja putri yang memiliki body image negatif cenderung memiliki tingkat aktivitas fisik yang rendah (Kololo et al., 2012). Pendapat tersebut bertolak belakang dengan penelitian yang dilakukan Ritan (2018) yang menyatakan bahwasanya body image negatif dapat membuat seseorang melakukan berbagai cara agar mendapatkan bentuk tubuh yang ideal, dengan melakukan aktivitas fisik secara berlebihan (Ritan et al., 2018).

Terdapat hasil studi yang berbeda terkait body image dengan tingkat aktivitas fisik begitu juga pada status gizi dengan tingkat aktivitas fisik pada remaja putri ditingkat SMA sederajat. Maka dari itu masih perlu diteliti hubungan body image dan status gizi terkait dengan aktivitas fisik pada remaja putri SMA dan SMK swasta wilayah kerja puskesmas pasundan Kota Samarinda tahun 2019.

\section{METODE}

Jenis penelitian ini adalah analitik kuantitatif dengan desain cross sectional. Penelitian ini dilaksanakan di SMA dan SMK swasta wilayah kerja puskesmas pasundan Kota Samarinda, pada bulan agustus 2019. Populasi dalam penelitian ini yaitu seluruh siswi SMA dan SMK swasta wilayah kerja puskesams pasundan kota samarinda tahun 2019. Sampel dalam penelitian ini yaitu siswi kelas $\mathrm{X}$ dan XI dengan rentan usia 15 - 17 tahun yang berjumlah 141 orang. Teknik sampling yang digunakan dalam pengambilan sampel yaitu probability sampling, dengan menggunakan stratified random sampling. Variabel dalam penelitian ini terdiri dari variabel independen yaitu body image dan status gizi, variabel dependen yaitu aktivitas fisik.

Pada penelitian ini data diambil menggunakan kuesioner yang telah terstandarisasi dan diadopsi kedalam bahasa Indonesia yaitu Physical Activity Questioner Adolescents (PAQ - A) untuk menilai aktivitas fisik (Kowalski et al., 2004), Multidemensional Body Self Relation Questioner Appearance Scale (MBSRQ-AS) untuk menilai body image (Cash, 2000), dan pengukuran status gizi menggunakan perhitungan IMT berdasarkan antropometri (Kemenkes, 
2011). Analisis data bivariat yang digunakan adalah uji korelasi spearman rank yang bertujuan untuk mengetahui hubungan body image dan status gizi dengan aktivitas fisik. Hubungan antar variabel dapat diketahui dengan membandingkan nilai pvalue dengan nilai $\alpha=0,05$.

\section{HASIL}

Hasil penelitian diperoleh gambaran karakteristik remaja putri SMA dan SMK swasta wilayah kerja puskesmas pasundan Kota Samarinda, dapa dilihat pada tabel 1.

Pada Tabel 1. berdasarkan frekuensi karakteristik responden diketahui bahwa distribusi frekuensi usia mayoritas 70 $(49,6 \%)$ responden berusia 16 tahun. Analisis univariat berdasarkan hasil observasi dan pengisian kuesioner physical activity questioner for and adolescents (PAQ - A) menunjukkan mayoritas responden $88(62,4 \%)$ memiliki aktivitas rendah, baik ketika berada di lingkungan sekolah maupun lingkungan rumah.

Tingkat aktivitas fisik yang rendah diperparah dengan kondisi yang menunjukkan bahwa sebagian besar responden memiliki body image negatif. Berdasarkan hasil pengisian kuesioner multidemensional body self relation questioner appearance scale (MBSRQ AS) ditemukan bahwasanya sebagian besar
$93(66,0 \%)$ responden memiliki body image negatif. Pengukuran status gizi menggunakan metode antropometri dan perhitungan IMT/U yang menunjukkan bahwa status gizi sebagian besar 93 $(66,0 \%)$ responden mempunyai status gizi normal.

Hasil analisis bivariat pada tabel 2 . diketahui bahwa sebanyak $54 \quad(58,1 \%)$ responden memiliki body image negatif dengan kategori aktivitas fisik rendah. Sebanyak 34 (70,8\%) responden memiliki body image positif dengan kategori aktivitas fisik rendah. Hasil analisis menggunakan uji spearman rank diperoleh pvalue sebesar 0,005 ( $\mathrm{p}<0,05)$ yang menunjukkan bahwa ada hubungan yang bermakna antara body image dengan aktivitas fisik remaja putri SMA dan SMK swasta wilayah kerja puskesmas pasundan Kota Samarinda tahun 2019.

Hasil analisis bivariat tabel 2 . diketahui bahwa sebanyak $61 \quad(65,6 \%)$ responden mempunyai status gizi normal dengan tingkat aktivitas fisik rendah. Sebanyak $1(5,6 \%)$ responden mempunyai status gizi obesitas dengan kategori aktivitas fisik tinggi. Hasil analisis menggunakan uji spearman rank diperoleh nilai pvalue sebesar 0,401 ( $\mathrm{p}>0,05)$ yang menunjukkan bahwa tidak ada hubungan yang signifikan antara status gizi dengan 
aktivitas fisik remaja putri SMA dan SMK swasta wilayah kerja puskesmas pasundan Kota Samarinda tahun 2019.

\section{PEMBAHASAN}

Hubungan antara Body Image dengan Aktivitas Fisik Remaja Putri SMA dan SMK Swasta Wilayah Kerja Puskesmas Pasundan Kota Samarinda Tahun 2019

Hasil studi ini menunjukkan terdapat hubungan body image dengan aktivitas fisik. Melalui uji statistik diketahui bahwa mayoritas proporsi responden yang memiliki body image negatif dengan kategori aktivitas fisik rendah sebanyak 54 $(58,1 \%)$. Penelitian ini didukung oleh hasil penelitian Sánchez-miguel (2017) yang menunjukkan bahwa remaja putri memiliki gangguan body image yang lebih tinggi mengenai tinggi badan, massa tubuh dan IMT dibandingkan dengan remaja laki laki, selain itu remaja putri juga memiliki waktu sedentary behaviour yang lebih tinggi dan niat yang lebih rendah untuk aktif secara fisik (Sánchez-miguel et al., 2017).

Uji spearman rank pada studi ini mendapatkan nilai pvalue 0,005 ( $\mathrm{p}<0,05)$. Hasil uji bivariat pada studi ini sejalan dengan hasil penelitian Kantanista (2015), yang menunjukkan adanya hubungan antara body image negatif dengan aktivitas fisik remaja putri $(\mathrm{p}<0,01)$. Hal ini menunjukkan bahwa tingkat kepuasan tubuh yang lebih rendah diperkirakan akan membuat tingkat aktivitas fisik menjadi rendah (Kantanista et al., 2015). Penelitian Finne (2011), menunjukkan adanya hubungan antara body image negatif dengan aktivitas fisik rendah dikalangan remaja putri $(\mathrm{p}<0,05)$ (Finne et al., 2011). Pada kelompok usia remaja khususnya remaja putri, ketidakpuasan tubuh dikaitkan dengan gangguan kesejahteraan emosional, gejala depresi yang meningkat, dan aktivitas fisik yang rendah (Craike et al., 2016).

Persepsi diri mengenai bentuk fisik adalah salah satu kunci untuk individu aktif dalam melakukan aktivitas fisik intensitas sedang hingga kuat, terutama untuk remaja putri (Finne et al., 2011). Berdasarkan distribusi jawaban responden pada kuesione PAQ - AS mengenai aktivitas fisik selama seminggu terakhir, penelitian ini menemukan bahwa tingkat aktivitas fisik responden tidak sesuai rekomendasi secara global. Terdapat 61 $(43,3 \%)$ responden melakukan aktivitas fisik sebanyak $1-2$ kali dalam satu minggu, durasi ini masih kurang dari yang direkomendasikan WHO. Sebanyak 28 $(19,9 \%)$ responden dari subjek penelitian yang melakukan aktivitas fisik sesuai rekomendasi WHO yaitu 3 - 4 kali dalam satu minggu untuk aktivitas fisik intensitas 
sedang dan $1(0,7 \%)$ responden yang memenuhi rekomendasi WHO 5-6 kali dalam satu minggu untuk aktivitas fisik intensitas kuat.

Secara teori, seseorang yang merasa tidak puas dengan citra tubuh (body image negatif) akan lebih cenderung terlibat untuk melawan ketidaknyamanan (Zaccagni et al., 2014). Teori tersebut tidak sejalan dengan hasil studi ini, dimana responden yang memiliki body image negatif memiliki tingkat aktivitas fisik rendah. Menurut Añez (2018) dalam studinya menunjukkan bahwa body image negatif berfungsi sebagai penghalang dan bukan sebagai motivator dalam melakukan aktivitas fisik dikalangan remaja putri Spanyol (Añez et al., 2018).

Hal ini perlu diperbaiki dimasa depan sebab individu yang memiliki body image negatif dimasa sekarang dapat merasakannya kembali dimasa yang akan datang. Memiliki masalah mengenai body image relatif umum terjadi dikalangan remaja putri, namun jika perasaan khawatir terhadap bentuk tubuh berkepanjangan maka dapat menjadi faktor risiko individu untuk mengalami masalah kesehatan mental. (Mark, 2019).

Dampak negatif lainnya yang akan muncul jika seseorang mempunyai ketidakpuasan citra tubuh (body image negatif) yaitu munculnya gangguan makan (eating disorder) yang merupakan penyakit kejiwaan ditandai dengan adanya gangguan tingkah laku/ kebiasaan makan, seperti mengurangi atau mengkonsumsi makanan dengan ekstrim dan perasaan menderita keprihatinan tentang berat badan yang terlalu ekstrim. Gangguan eating disorder yang berkepanjangan akan menimbulkan malnutrisi dikalangan remaja putri (Dwintasari, 2018).

Deteksi dini mengenai body image dapat membantu mencegah permasalahan kesehatan seperti risiko gangguan mental dan eating disorder. Penting adanya intervensi kesehatan seperti peningkatan aktivitas fisik untuk memperbaiki persepsi body image negatif dikalangan remaja putri. Aktivitas fisik yang dilakukan secara rutin dapat membantu dalam memperbaiki persepsi remaja putri mengenai body image. Membuat sebuah progam kesehatan terpadu, dengan memasukkan unsur kesehatan didalam kegiatan belajar mengajar disekolah. Meningkatkan inovasi program untuk menangulangi masalah kesehatan remaja, dengan melibatkan kerjasama lintas sektor.

Hubungan antara Status Gizi dengan Aktivitas Fisik Remaja Putri SMA dan SMK Swasta Wilayah Kerja Puskesmas Pasundan Kota Samarinda Tahun 2019 
Hasil studi ini menunjukkan tidak terdapat hubungan status gizi dengan aktivitas fisik. Melalui uji statistik diketahui bahwa mayoritas proporsi responden memiliki status gizi normal dengan kategori aktivitas fisik rendah sebanyak 61 (65,6\%). Uji spearman rank pada studi ini mendapatkan nilai pvalue 0,401 ( $\mathrm{p}>0,05)$. Hasil penelitian ini sejalan dengan penelitian Karimah, (2014) yang menunjukkan bahwa tidak terdapat hubungan status gizi dengan aktivitas fisik ( $p>0,05)$ (Karimah, 2014).

Hasil penelitian diatas berbeda dengan penelitian Putra (2018), dalam penelitian tersebut ditemukan bahwa mayoritas responden memiliki status gizi normal dengan tingkat aktivitas fisik sedang, terdapat hubungan status gizi dengan aktivitas fisik (Putra et al., 2018). Penelitian yang dilakukan oleh Yulia (2018) menemukan bahwa dari 300 responden terdapat $(71,6 \%)$ anak dengan status gizi normal memiliki aktivitas fisik ringan. Pada penelitian ini diketahui aktivitas menetap anak - anak di waktu luang (libur sekolah) dengan waktu sekolah tidak berbeda secara signifikan diantara responden yang mempunyai status gizi kurus, normal, gemuk dan obesitas (Yulia et al., 2018).
Ditinjau dari sudut pandang siswa, terdapat beberapa hal penting yang menjadi penghambat untuk melakukan kegiatan fisik termasuk pendidikan, kurangnya tempat yang tepat untuk berolahraga, kurangnya waktu, dan kelelahan (Najarkolaei et al., 2015). Aktivitas anak sekolah rata - rata seragam, sebagian besar waktunya banyak digunakan untuk kegiatan belajar dan bermain yang memerlukan sedikit pengeluaran energi (Karimah, 2014).

Tingkat aktivitas fisik yang rendah di semua kategori status gizi kemungkinan dapat disebabkan tidak adanya dorongan dari dalam diri untuk melakukan aktivitas fisik dapat menjadi salah satu faktor penyebab rendahnya tingkat aktivitas fisik di semua kategori status gizi (Najarkolaei, 2015). Sejalan dengan teori Najarkolaei (2015), theory of Reasoned Action (TRA) terdiri dari 7 komponen, antara lain behaviour belief, normative belief, attitude, importance norms, subjektif norms, behaviour intention, dan behaviour.

Praktik atau perilaku menurut TRA dipengaruhi oleh niat, sedangkan niat dipengaruhi oleh sikap dan norma subjektif. Sikap dipengaruhi oleh keyakinan dari hasil tindakan yang telah lalu. Norma subjektif dipengaruhi oleh keyakinan akan pendapat orang lain serta 
motivasi untuk mentaati pendapat tersebut (Priyoto, 2014). Teori ini menjelaskan bahwa perilaku seseorang dapat dipengaruhi banyak faktor seperti niat, sikap, keyakinan, motivasi, dan norma subjektif. Hal ini sama seperti perilaku aktivitas fisik yang kemungkinan tidak hanya dipengaruhi oleh status gizi, sehingga pada penelitian ini tidak terdapat hubungan antara status gizi dengan aktivitas fisik.

Penelitian ini belum bisa membuktikan bahwa status gizi individu dapat mempengaruhi tingkat aktivitas fisik, karena semua kelompok status gizi mempunyai frekuensi aktivitas fisik yang cenderung sama yaitu rendah. Hal ini perlu diperbaiki dimasa depan sebab remaja pada masa usia sekolah merupakan periode kritis dalam perkembangan perilaku kesehatan karena aktivitas fisik selama masa remaja telah dikaitkan dengan tingkat aktivitas fisik di masa dewasa. Individu dengan aktivitas fisik rendah pada masa remaja memiliki risiko yang lebih besar untuk mengalami penurunan tingkat aktivitas fisik di usia dewasa khususnya dikalangan perempuan (Litt, Iannotti, \& Wang, 2011).

Diperlukan kerjasama lintas sektor pendidikan dan kesehatan, penguatan intervensi kesehatan melalui program
Gerakan Masyarakat Hidup Sehat (GERMAS) untuk mewujudkan perilaku sehat pada remaja putri yang bersekolah di SMA dan SMK swasta wilayah kerja puskesmas pasundan Kota Samarinda tahun 2019.

\section{KESIMPULAN DAN SARAN}

Kesimpulan yang didapatkan dari hasil penelitian ini yaitu mayoritas remaja putri SMA dan SMK swasta wilayah kerja puskesmas pasundan Kota Samarinda tahun 2019 memiliki persepsi body image negatif sebanyak $93(66,0 \%)$ orang, berada pada status gizi normal sebanyak 93 $(66,0 \%)$ orang dan sebanyak $88(62,4 \%)$ orang memiliki tingkat aktivitas fisik yang rendah. Uji korelasi spearman rank menunjukkan bahwa terdapat hubungan yang signifikan pada variabel body image dengan aktivitas fisik remaja putri SMA dan SMK swasta wilayah kerja puskesmas pasundan Kota Samarinda tahun 2019 dengan nilai $(\mathrm{p}=0,005)$, namun tidak terdapat hubungan pada variabel status gizi dengan aktivitas fisik remaja putri SMA dan SMK swasta wilayah kerja puskesmas pasundan Kota Samarinda tahun 2019 dengan nilai $(\mathrm{p}=0,401)$.

Perlu adanya proses pembelajaran dengan memodifikasi metode pembelajaran sehingga aktivitas fisik tidak 
hanya terkait dengan mata pelajaran olahraga. Pemberian edukasi dari pihak puskesmas mengenai persepsi body image dan pentingnya melakukan aktivitas fisik (olahraga) untuk setiap harinya, melalui kegiatan sosialisasi ke sekolah - sekolah, sekaligus pembentukan duta GERMAS melalui kegiatan pemberdayaan disekolah, dengan mengajarkan para siswa/i untuk dapat memimpin gerakan peregangan sebelum mata pelajaran dimulai.

\section{REFERENSI}

Añez, E., Fornieles-deu, A., Fauquet-ars, J., López-guimerà, G., Puntí-vidal, J., \& Sánchez-carracedo, D. (2018). Body image dissatisfaction, physical activity and screen-time in Spanish adolescents. Journal of Health Psychology, 23(1), 36-47. https://doi.org/10.1177/13591053166 64134. Diakses 10 - 06 - 2019

Cash, T. F. (2000). The multidimensional body-self relations questionnaire. (2), 1-12. Retrieved from https://mafiadoc.com/mbsrq-usermanual-3rded_59ccec101723ddd52081b4ef.html. Diakses 05 - 05 - 2019

Craike, M., Young, J. A., Symons, C. M., Pain, M. D., Harvey, J. T., Eime, R. M., \& Payne, W. R. (2016). Trends in body image of adolescent females in metropolitan and non-metropolitan regions: a longitudinal study. $B M C$ Public Health, 16(1), 1-9. https://doi.org/10.1186/s12889-0163815-1. Diakses 12 - 06 - 2019

Finne, E., Bucksch, J., Lampert, T., \& Kolip, P. (2011). Age , puberty , body dissatisfaction, and physical activity decline in adolescents. Results of the German Health Interview and
Examination Survey ( KiGGS ). International Journal of Behavioral Nutrition and Physical Activity, 8(1), 119. https://doi.org/10.1186/14795868-8-119. Diakses 10 - 08 - 2019

Habut, M. Y., Nurmawan, I . P. S., Wiryanthini, I. A. D. (2015). Hubungan Indeks Massa Tubuh dan Aktivitas Fisik Terhadap Keseimbangan Dinamis Pada Mahasiswa Fakultas Kedokteran Universitas Udayana. Majalah Ilmiah Fisioterapi Indonesia, 2, 45-51. Retrieved from file:///C:/Users/ASUS-

PC/Downloads/22087-1-42985-1-1020160715.pdf. Diakses 12 - 05 - 2019 Kantanista, A., Osi, W., Borowiec, J., Tomczak, M., \& Król-zieli, M. (2015).

Body image , BMI, and physical activity

in girls and boys aged $14-16$ years. Journal Elsevier, 15, 40-43. https://doi.org/10.1016/j.bodyim.2015 .05.001. Diakses 12 - 08 - 2019

Karimah, I. (2014). Aktivitas Fisik, Kebugaran, dan Prestasi Belajar Pada Anak Sekolah Dasar Normal dan Kegemukan di Bogor (Intitut Pertanian Bogor). Retrieved from https://repository.ipb.ac.id/jspui/bitstr eam/123456789/68736/1/2014ika.pdf. Diakses 12 - 08 - 2019

Kawuwung, K. S., Rompas, S., Onibala, F. (2015). Hubungan Obesitas dengan Citra Tubuh dan Harga Diri Pada Remaja Putri Program Studi Ilmu Keperawatan Fakultas Kedokteran Universitas Sam Ratulangi. E-Journal Keperawatan, 3. Retrieved from https://ejournal.unsrat.ac.id/index.php /jkp/article/view/8082. Diakses 05 $08-2019$

Kemenkes, R. (2011). Buku sk antropometri (p. 41). p. 41. 
https://doi.org/10.1055/s-0029-

1219204. Diakses 10 - 05 - 2019

Kementerian Kesehatan RI. (2008). Riset

Kesehatan Dasar 2007.

https://doi.org/10.1007/BF00006513.

Diakses 10 - 05 - 2019

Kementerian Kesehatan RI. (2018). Riset Kesehatan Dasar 2018. https://doi.org/1 Desember 2013. Diakses 10 - 05 - 2019

Kololo, H., Guszkowska, M., Mazur, J., \& Dzielska, A. (2012). Self-efficacy, self-esteem and body image as psychological determinants of 15year-old adolescents' physical activity levels. Human Movement, 13(3), 264270. https://doi.org/10.2478/v10038012-0031-4. Diakses 10 - 05 - 2019

Kowalski, K., Crocker, P., \& Donen, R. (2004). The Physical Activity Questionnaire for Older Children (PAQ-C) and Adolescents (PAQ-A) Manual Examining the Physical Self in Adolescent Girls Over Time: Further Evidence Against the Hierarchical Model. Retrieved from https://www.prismsports.org/UserFile s/file/PAQ_manual_ScoringandPDF.p df. Diakses 20 - 05 - 2019

Li, W. G., Procter, E., Churchill, L., Crouter, S.E., Kane, K., Cheng J., Rui, F., Tian, J., Franklin, P. D., Ockene, J.K. , and Gurwitz, J. (2017). Gender and Age Differences in Levels, Types and Locations of Physical Activity among Older Adults Living in Car-Dependent Neighborhoods. The Journal of Frailty \& Aging, 6(3), 129-135. https://doi.org/10.14283/jfa.2017.15.

Diakses 05 - 06 - 2019

Litt, D. M., Iannotti, R. J., \& Wang, J. (2011). Motivations for Adolescent Physical Activity. Journal of Physical and Health, 8, 220-226. Retrieved from

https://pdfs.semanticscholar.org/2992/ 9f82beb39calaa545375c1802f892c01 8c93.pdf. Diakses 12 - 08 - 2019

Mark, R. (2019). Body Image. Retrieved from file:///C:/Users/ASUSPC/Downloads/DqVNbWRVvpAPQz w.pdf. Diakses 05 - 01 - 2020

McGuire, K. A., \& Ross, R. (2012). Incidental physical activity and sedentary behavior are not associated with abdominal adipose tissue in inactive adults. Obesity, 20(3), 576582.

https://doi.org/10.1038/oby.2011.278. Diakses 12 - 08 - 2019

Najarkolaei, F. R.-, Talatappeh, H. D., \& Naghavi, S. (2015). Physical Activity and Nutrition Status in the University Students: A Mix method Study. Journal of Health Policy and Sustainable Health, 2(2), 201-206. Retrieved from https://journals.bmsu.ac.ir/jhpsh/index .php/jhpsh/article/view/53. Diakses 10 - $06-2019$

Putra, Yudha Wahyu, A. S. R. (2018). Index Massa Tubuh (IMT) Mempengaruhi Aktivitas Remaja Putri Smp Negeri 1 Sumberlawang. Gaster | Jurnal Ilmu Kesehatan, 16(1), 105. https://doi.org/10.30787/gaster.v16i1. 23

RISKESDAS. (2013). RISET KESEHATAN DASAR; Badan Penelitian dan Pengembangan Kesehatan Kementerian Kesehatan RI Tahun2013. Laporan Nasional 2013, 1-384. https://doi.org/1 Desember 2013. Diakses 10 - 05 - 2019

Ritan, A. F. G., Murdiono, W. R., Syafitri, E. N., Studi, P., Keperawatan, S.-I., \& Respati, U. (2018). Hubungan body image dengan pola makan dan aktivitas fisik pada mahasiswa obesitas di Fakultas Ilmu Kesehatan Universitas Respati Yogyakarta. Ilmu Gizi Indonesia, 02(01), 25-32. Retrieved from http://ilgi.respati.ac.id/index.php/ilgi2 
017/login?source $=\% 2$ Findex.php $\% 2 \mathrm{~F}$ ilgi2017\%2Farticle\%2Fview\%2F85.

Diakses 10 - 05 - 2019

Sánchez-miguel, P. A., Leo, F. M., Amado, D., Pulido, J. J., \& Sánchezoliva, D. (2017). Relationships Between Physical Activity Levels, Self-Identity , Body Dissatisfaction and Motivation Among Spanish High School Students by. Journal of Human Kinetics, 59, 29-38. https://doi.org/10.1515/hukin-2017-

0145. Diakses 15 - 08 - 2019

Utami, T. Widya Wira, Bebasari, Eka, Ernalia, Y. (2015). Relationship Of Physical Activity Levels With Genesis Obesity In Faculty Of Medicine University Of Riau Generation 2012 \& 2013. Jurnal Online Mahasiswa Fakultas Kedokteran, 2(2). Retrieved from https://jom.unri.ac.id/index.php/JOM FDOK/article/view/6462/6160.

Diakses 15 - -8 - 2019

Waghachavare, V. B., Dhumale, G. B., Kadam, Y. R., \& Gore, A. D. (2014). A Study of Stress among Students of Professional Colleges from an Urban Area in India. Sultan Qaboos University Medical Journal, 13(3), 422-429.

https://doi.org/10.12816/0003266.

Diakses 15 - 08 - 2019

WHO. (2010). Global Recommendations On Physical Activity For Health (World Health Organization, Ed.). Retrieved from https://www.who.int/dietphysicalactiv ity/global-PA-recs-2010.pdf. Diakses
20 - $06-2019$

WHO. (2018). Global Action Plan On Physical Activity 2018 - 2030 More Active People For A HealthHier WOrld. Retrieved from https://apps.who.int/iris/bitstream/han dle/10665/272721/WHO-NMH-PND18.5-eng.pdf. Diakses 20 - 06 - 2019

Wiranatha, F. D., \& Supriyadi. (2015). Hubungan Antara Citra Tubuh dengan Kepercayaan Diri pada Remaja Pelajar Puteri di Kota Denpasar. Jurnal Psikologi Udayana, 2(1), 3847. Retrieved from https://ojs.unud.ac.id/index.php/psikol ogi/article/view/25139/16350.

Diakses 12 - 08 - 2019

Yulia, C., Sukandar, D., \& Riyadi, H. (2018). Nutritional Status , Physical Activity , Sedentary Activity of School Children in Urban area, West Java, Indonesia Nutritional Status , Physical Activity, Sedentary Activity of School Children in Urban area, West Java , Indonesia. Journal Gizi Pangan, 13(3), 123-130. https://doi.org/10.25182/jgp.2018.13. 3. Diakses 12 - 08 - 2019

Zaccagni, L., Masotti, S., Donati, R., Mazzoni, G., \& Gualdi-Russo, E. (2014). Body image and weight perceptions in relation to actual measurements by means of a new index and level of physical activity in Italian university students. Journal of Translational Medicine, 12(1), 1-8. https://doi.org/10.1186/1479-587612-42. Diakses 12 - 08 - 2019 
Tabel 1. Distribusi Karakteristik Responden dan Variabel Univariat Remaja Putri SMA \& SMK Swasta Wilayah Kerja Puskesmas Pasundan Kota Samarinda tahun 2019

\begin{tabular}{lcc}
\hline $\begin{array}{l}\text { Karakteristik Responden } \\
\text { (usia) }\end{array}$ & Frekuensi & Persentase (\%) \\
\hline 15 tahun & 65 & 46,1 \\
16 tahun & 70 & 49,6 \\
17 tahun & 6 & 4,3 \\
Variabel Univariat & & \\
Aktivitas Fisik & 24 & 17,0 \\
Sangat rendah & 88 & 62,4 \\
Rendah & 28 & 19,9 \\
Sedang & 1 & 0,7 \\
Tinggi & & \\
Body Image & 93 & 66,0 \\
Negatif & 48 & 34,0 \\
Positif & & \\
Status Gizi & & \\
Kurus & 7 & 5,0 \\
Normal & 93 & 66,0 \\
Gemuk & 23 & 16,3 \\
Obesitas & 18 & 12,8 \\
\hline Total & $\mathbf{1 4 1}$ & $\mathbf{1 0 0 , 0}$ \\
\hline
\end{tabular}

Tabel 2. Analisis Variabel Bivariat Remaja Putri SMA \& SMK Swasta Wilayah Kerja Puskesmas Pasundan Kota Samarinda tahun 2019

\begin{tabular}{|c|c|c|c|c|c|c|c|c|c|c|c|}
\hline \multirow{3}{*}{$\begin{array}{l}\text { Body } \\
\text { Image }\end{array}$} & \multicolumn{8}{|c|}{ Aktivitas Fisik } & \multirow{2}{*}{\multicolumn{2}{|c|}{ Total }} & \multirow[t]{3}{*}{ pvalue } \\
\hline & \multicolumn{2}{|c|}{$\begin{array}{l}\text { Sangat } \\
\text { Rendah }\end{array}$} & \multicolumn{2}{|c|}{ Rendah } & \multicolumn{2}{|c|}{ Sedang } & \multicolumn{2}{|c|}{ Tinggi } & & & \\
\hline & $\mathbf{n}$ & $\%$ & $\mathbf{n}$ & $\%$ & $\mathbf{n}$ & $\%$ & $\mathbf{n}$ & $\%$ & n & $\%$ & \\
\hline Negatif & 14 & 15,1 & 54 & 58,1 & 24 & 25,8 & 1 & 1,1 & 93 & 100 & \\
\hline Positif & 10 & 20,8 & 34 & 70,8 & 4 & 8,3 & 0 & 0 & 48 & 100 & 0,005 \\
\hline Total & 24 & 17,0 & 88 & 62,4 & 28 & 19,9 & 1 & 0,7 & 141 & 100 & \\
\hline \multicolumn{12}{|c|}{ Status Gizi } \\
\hline Kurus & 1 & 14,3 & 6 & 85,7 & 0 & 0 & 0 & 0 & 7 & 100 & \\
\hline Normal & 15 & 16,1 & 61 & 65,6 & 17 & 18,3 & 0 & 0 & 93 & 100 & \\
\hline Gemuk & 5 & 21,7 & 12 & 52,2 & 6 & 26,1 & 0 & 0 & 23 & 100 & 0,401 \\
\hline Obesitas & 3 & 16,7 & 9 & 50,0 & 5 & 27,8 & 1 & 5,6 & 18 & 100 & \\
\hline Total & 24 & 17,0 & 88 & 62,4 & 28 & 19,9 & 1 & 0,7 & 141 & 100 & \\
\hline
\end{tabular}

